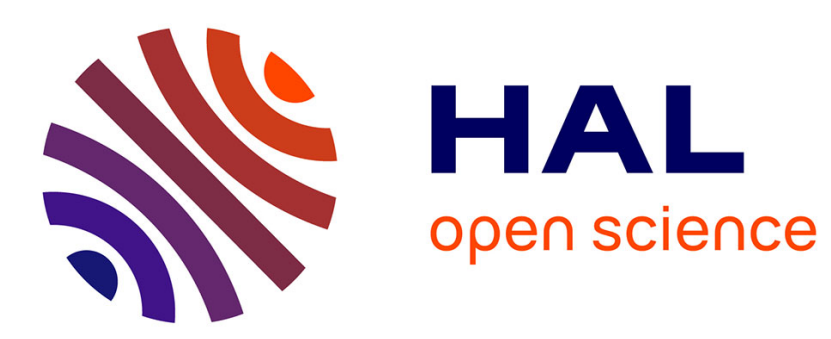

\title{
Cleaner Production Evaluation Model: Multiple Case Study in the Plastic Industry
}

Dalton Oswaldo Buccelli, Pedro De Oliveira Costa Neto

\section{To cite this version:}

Dalton Oswaldo Buccelli, Pedro De Oliveira Costa Neto. Cleaner Production Evaluation Model: Multiple Case Study in the Plastic Industry. IFIP International Conference on Advances in Production Management Systems (APMS), Sep 2014, Ajaccio, France. pp.3-13, 10.1007/978-3-662-44736-9_1. hal-01387838

\section{HAL Id: hal-01387838 \\ https://inria.hal.science/hal-01387838}

Submitted on 26 Oct 2016

HAL is a multi-disciplinary open access archive for the deposit and dissemination of scientific research documents, whether they are published or not. The documents may come from teaching and research institutions in France or abroad, or from public or private research centers.
L'archive ouverte pluridisciplinaire HAL, est destinée au dépôt et à la diffusion de documents scientifiques de niveau recherche, publiés ou non, émanant des établissements d'enseignement et de recherche français ou étrangers, des laboratoires publics ou privés. 


\title{
CLEANER PRODUCTION EVALUATION MODEL: MULTIPLE CASE STUDY IN THE PLASTIC INDUSTRY
}

\author{
Dalton Oswaldo Buccelli, Pedro Luiz de Oliveira Costa Neto \\ Paulista University-UNIP, Graduate Program in Production Engineering, \\ Dr. Bacelar St. 1212, São Paulo, Brazil \\ \{Dalton Oswaldo Buccelli - dalton_buccelli@uol.com.br; \\ Pedro Luiz de Oliveira Costa Neto - politeleia@uol.com.br\}
}

\begin{abstract}
This paper reports a study on the cleaner production program developed in the plastic industry in São Paulo - Brazil. An evaluation model was developed, using as reference the existing literature on business models and process management, as well as excellence models adopted by national quality awards from different countries. The model was applied for in-depth multiple case study in eight plastic companies to validate the importance of management processes in the implementation of cleaner production programs and to observe the results obtained with the cleaner production initiatives. The research has identified two companies with more than $92 \%$ compliance to the model which reached important environmental results in the last three years. The results are supplemented with the use of external performance indicators (material intensity, water and carbon footprint savings) to show that little changes inside the companies can reduce upstream impacts and bring greater benefits to the environment.
\end{abstract}

Keywords: Cleaner production, Environmental indicators, Management processes, Management quality, Plastic industry.

\section{Introduction}

Stone [1] explains that the most common types of changes that are demonstrated by cleaner production case studies are technical, but these types of changes is unlikely to be enough by itself to bring about cleaner production in organizations. This is because of the human dimensions of organizational change. Taylor [2] recommends the use of tools for behavior change in the context of removing the identified barriers. These change tools could be: obtaining introductory commitments prior to larger requests; providing reminder prompts in appropriate locations; development of community social norms (peer pressure); credible and appropriate communication; and providing incentives.

Vendrametto et al [3] conclude that it is better to use a combination of strategies, as well as awareness speeches, technical training and presentation of success cases to disseminate new approaches in the industrial sector, but initiatives to implement cleaner production opportunities were more effective in companies that had tried other methods to improve production processes, such as Lean Manufacturing and Total Quality Management. These organizations primarily seek to structure their management process as a way to make the initiatives solid and permanent. This is part of the absorptive capacity created with the former experience.

Taking into account these statements and experiences of experts, it is possible to assume that the presence of principles and concepts of cleaner production embedded in the management processes of the business is essential for effective implementation of projects to improve the products and operational processes (value chain), allowing them to achieve positive and lasting environmental results. This initiative requires an action that complements the technical knowledge and incorporates cleaner production concepts and principles into the management processes of companies to get permanent improvements in efficiency of production processes, minimize environmental impacts and increase performance indicators results.

The plastic industry brought the interest in analyzing the effectiveness of recent cleaner production initiatives implemented in the sector. The study began with the development of 
a model for evaluating the incorporation of cleaner production principles in the management processes of companies. The model was created using as reference the existing literature on business models and process management, as well as excellence models adopted by national quality awards from different countries. After that it was applied during multiple case study, a qualitative research to bring a deeper knowledge on key management processes to achieve positive and lasting results.

Two of the eight companies participating in the research were identified by the assessment model as having management processes with structured principles of cleaner production. Over the last three years consistent results were observed in internal environmental indicators such as reduction in consumption of fossil materials, water and electricity. These results were supplemented with calculations of external performance indicators (material intensity, water and carbon footprint savings), allowing to understand the consumption decreases from the nature perspective and showing that even small internal changes to the company can bring big benefits to the environment and society that would not be perceived with restricted use of internal indicators.

\section{Business Processes and Cleaner Production in Plastic Industry}

\subsection{Business processes}

Gonçalves [4] defines process as any activity or set of activities that receive an "input", adds value and provides an "output" to a specific customer. He classifies the processes of organizations in three categories: Primary Processes; Support Processes; and Business Processes. The French standard AFNOR FD X 50-176 [5] recommends the classification of business processes in families to facilitate their identification and suggests the following grouping: Realization Processes; Supporting Processes; and Management Processes.

Rummler and Brache [6] subdivide existing activities in any company in three types of business processes: primary (processes that belong to the value chain; create products and services that meet the customer needs), auxiliary (processes that support primary processes) and management (processes that govern the operation of the company). Primary processes are concerned to sell, produce, deliver, provide technical assistance, improve and, where necessary, discontinue the product. Auxiliary processes are related to buy materials, recruit and select staff, maintain the company's equipment in working order, control the resources needed to build the product. However, the management processes are related to corporate governance, strategy formulation and deployment, goal setting, information management, definition of guidelines and organizational procedures, knowledge management and customer relationship. The third type of process acquires a prominent position due to assume important guidance and coordination with the other two types of processes.

\subsection{Cleaner Production in Plastic Industry}

The concept of cleaner production (CP) as the continuous application of an integrated preventative environmental strategy to processes, products and services to increase efficiency and reduce risks to humans and the environment, was first used in 1989 by the United Nations Environment Programme (UNEP) and in recent years has progressively being incorporated into the agenda of the business world. The basic $\mathrm{CP}$ principle is the implementation of advanced processes, technologies and equipment, improvement of management and comprehensive utilization of resources to reduce pollution at source, enhance the rates of resource utilization efficiency, reduce and/or avoid pollution generation and discharge in the course of production, provision of services and product use - so as to decrease the high cost generated by company's waste - and the increasingly scarce inputs like water and energy for society as a whole. According to Giannetti et al [7] this concept was developed as a further challenge of continuous improvement on leading companies, to become an integral part of business. The CP can be applied to processes used in any industry, its products and various services provided. It is a broad term that 
encompasses other associated terms such as eco-efficiency, pollution prevention (P2), waste minimization and green production.

The plastic industry is a very important sector of the Brazilian economy, containing about twelve thousand companies and contributing significantly to the generation and distribution of wealth in the country, and being the third largest employer in the manufacturing sector with three hundred and forty eight thousand jobs, produced 6.66 thousand tons of plastic materials, generating about R \$ 54 billion in 2012. Most companies in the industry are classified as micro and small enterprises employing less than 100 people and are located in the south and southeast regions of the country, which, together, account for more than $85 \%$ of the total. São Paulo State is the largest plastic manufacturer contributing with $45 \%$ of plastic industry gross revenues. The publication of the Technical Environmental Guide for Plastic Industry - CETESB [8] responds to unanimous global diagnosis that path to socioeconomic prosperity necessarily involves the sustained growth of industrial activity. This guide is part of the CP series of publications by CETESB which contributes to the precepts of sustainable development. In its pages can be found details on the practical implementation of cleaner production's concept specially designed by a group of industry experts to disseminate information and provide guidelines for employers and employees who work directly or indirectly with the plastic industry, as well as other interested parties in understanding the pathways that can lead to environmental preservation.

\section{Methodology}

\subsection{Literature review and model building}

In order to build a model for assessing environmental results and the introduction of $\mathrm{CP}$ concepts and principles into structured and standardized management processes, an extensive literature review was performed on organizational processes, as well as requirements and criteria to evaluate excellence in management processes, particularly those adopted in national and international quality awards [9].

It is amazing the coincidence in the various approaches to business processes found in the literature review. While adopting proper terms, the types of processes and their meanings are very similar and, according to the subdivision of the business processes proposed by these references, management processes are those that ensure the coherence and integration of core business and support processes.

Management processes play a key role in the coordination and guidance of the other two types of processes (primary/core and auxiliary/support), and help leaders during decision making activities. Their proper structuring is essential for core business and support processes carrying out according to the guidelines established by the leadership and to measure, monitor and improve the performance of the organization.

The model with four macro-management processes (a-Governance, leadership and planning; b-Market, customer and society relationship; c-People and knowledge management; d-Management of core and support processes) and one group of environmental indicators was applied during the qualitative research with eight plastic companies from São Paulo State Plastic Industry Association (SINDIPLAST) to evaluate companies' environmental performance through the implementation of cleaner production opportunities.

\subsection{Multiple case study}

According to Leonard-Barton [10], a case study is a history of past or current phenomena, drawn from multiple sources of evidence. It can include data from direct observation and systematic interviewing, as well as from public and private archives. Yin [11] adds that a case study is a complete research strategy which allows questions such as 'how' and 'why' to be studied. This strategy is moreover applicable to processes or to 
phenomena which have not yet been studied in depth. The author shows that the multiplication of cases is comparable with a multiplication of experiments, but the selection of case studies must be based on the principles of literal and theoretical replication. The former involves the selection of cases with apparently similar conditions and results; the latter requires cases which produce different results for more or less explicable reasons. The replication is based on theory and not on the statistical principle of sampling. These measures can help to reduce the degree of bias that the researcher is probably undergoing.

Based on these explanations eight plastic producers accepted to participate in the multiple case study to evaluate their management practices and environmental results. The form containing 20 statements about management processes and their examples of existing management practices, as well as 5 statements about outputs and examples of environmental indicators over the past three years was sent to fill.

In the first stage, all eight firms submitted the answered form and assigned the scores they considered appropriate to each of the statements related to existing management processes and the results achieved. Then these questionnaires were analyzed by the authors, who raised some points to be checked during a field visit.

To confirm the data previously collected a semi-structured interview was used. Managers and supervisors were interviewed to address the questions raised during the analysis of the questionnaires. Direct observation occurred during the field visits conducted by the authors. This technique was useful for providing additional information about good management practices and companies' results. Internal indicators were analyzed like as water consumption $\left(\mathrm{m}^{3}\right.$ of water / tone of finished product), electric energy consumption (MWh / tone of finished product), plastic waste during production process (tone of plastic / tone of finished product), and product scrap (tone of product scrap / tone of finished product).

To provide a broader vision of the results presented during the visits, to allow consistent evaluation of the benefits achieved from the savings and to compare results from different companies, producing distinct products and volumes, three methods were employed: Material intensity evaluation, Water footprint and Carbon footprint [12].

\section{Results and Discussion}

Eight companies were visited to verify if they had structured management processes deployed throughout the organization and other stakeholders. The form containing 20 statements about management processes and examples of existing management practices was grouped in 4 categories: a) Governance, Leadership and Planning; b) Society Relationship, Market and Customers; c) People and Knowledge Management; d) Management of Core Business and Support Processes. It was also possible to verify the environmental results obtained in the last three years. The full research form was completed by the responsible managers in each company and the answers were used as a guide of semi-structured interviews.

Table 1. Percentages of companies' compliance with the model.

\begin{tabular}{|c|c|c|c|c|c|c|c|c|c|}
\hline & \multicolumn{8}{|c|}{ \% of Companies' Compliance } \\
\hline & & $\mathrm{A}$ & $\mathrm{B}$ & $\mathrm{C}$ & $\mathrm{D}$ & $\mathrm{E}$ & $\mathrm{F}$ & $\mathrm{G}$ & $\mathrm{H}$ \\
\hline & $\begin{array}{l}\text { Governance, Leadership and } \\
\text { Planning Processes }\end{array}$ & 84.0 & 76.0 & 100.0 & 100.0 & 48.0 & 84.0 & 100.0 & 100.0 \\
\hline b) & $\begin{array}{l}\text { Society Relationship, Market } \\
\text { and Customers Processes }\end{array}$ & 92.0 & 56.0 & 92.0 & 84.0 & 84.0 & 92.0 & 100.0 & 92.0 \\
\hline c) & $\begin{array}{l}\text { People and Knowledge } \\
\text { Management Processes }\end{array}$ & 76.0 & 92.0 & 84.0 & 92.0 & 62.0 & 92.0 & 92.0 & 84.0 \\
\hline & $\begin{array}{l}\text { Management of Core and } \\
\text { Support Processes }\end{array}$ & 100.0 & 92.0 & 68.0 & 100.0 & 62.0 & 92.0 & 100.0 & 92.0 \\
\hline & vironmental Results & 68.0 & 60.0 & 76.0 & 84.0 & 24.0 & 68.0 & 84.0 & 54.0 \\
\hline & TOTAL COMPLIANCE & 84.0 & $\mathbf{7 5 . 2}$ & 84.0 & 92.0 & 56.0 & 85.6 & 95.2 & 84.4 \\
\hline
\end{tabular}


Table 1 presents the percentages of the management processes and environmental indicators results in compliance with the requirements of the model. As can be seen, companies D and G obtained $92.0 \%$ and $95.2 \%$ of the total compliance with the model, demonstrating the existence of structured management processes and sustainable results in environmental performance indicators. Companies $\mathrm{A}, \mathrm{C}$ and $\mathrm{F}$ presented recent environmental results during the review and still don't demonstrate positive trends. The other three companies could not show historical data to demonstrate indicators evolution and this fact is related with some missing management processes like leadership and strategic planning, customer relationship, people and knowledge management.

During the visit companies D and G presented improvement actions taken based on the 29 cleaner production opportunities proposed in the technical guide [8]. It may be noted that these companies had seriously adopted the recommendations of the guide and could show consumption reduction results. Table 2 presents major actions implemented by these two companies and their positive impact (reductions) on environment.

Table 2. Major cleaner production interventions.

\begin{tabular}{|c|c|c|c|c|}
\hline \multirow{2}{*}{$\begin{array}{c}\text { Cleaner Production } \\
\text { Interventions (Technical Guide) }\end{array}$} & \multicolumn{4}{|c|}{ Reduction } \\
\hline & $\mathbf{H}_{2} \mathbf{O}$ & $\begin{array}{c}\text { Natural } \\
\text { Resources }\end{array}$ & $\begin{array}{c}\text { Energy } \\
\text { Consumption }\end{array}$ & $\begin{array}{c}\text { Solid } \\
\text { Waste }\end{array}$ \\
\hline $\begin{array}{l}\text { Opp3 - Use of new technologies for energy saving and } \\
\text { productivity increase }\end{array}$ & & $X$ & $X$ & $X$ \\
\hline $\begin{array}{l}\text { Opp4 - Optimize the logistics of raw materials and use of more } \\
\text { economical and returnable packaging }\end{array}$ & $X$ & $X$ & & $X$ \\
\hline Opp5 - Reprocessing of no conforming materials & & $X$ & & $X$ \\
\hline Opp6 - Improvement in equipment sizing - Production Planning & & & $X$ & $X$ \\
\hline Opp7-Predictive, preventive and corrective maintenance & $X$ & $X$ & $X$ & $X$ \\
\hline Opp8 - Continuing education of production workers & $X$ & $X$ & $X$ & $X$ \\
\hline Opp9 - Efficient Lighting and translucent tiles & & & $X$ & \\
\hline Opp 11 - Use of additives in the process water & $X$ & & & \\
\hline Opp12 - Adoption of efficient cooling towers & $X$ & & $X$ & \\
\hline Opp14 - Use of cooling towers and closed circuit & $X$ & & & \\
\hline Opp16 - Use of water saving devices & $X$ & & & \\
\hline Opp19 - Avoid losses due to problems in compressed air piping & & $X$ & $X$ & \\
\hline Opp22 - Energy diagnosis & & & $X$ & \\
\hline
\end{tabular}

Internal indicators - Material and energy savings per tons of finished product (tfp) were verified during the visits. The total reduction in water consumption, electric energy consumption and plastic material consumption after three years of $\mathrm{CP}$ interventions are shown in Table 3.

Table 3. Reductions after three years of $\mathrm{CP}$ interventions.

\begin{tabular}{lcc}
\cline { 2 - 3 } Total Savings & Company D & Company G \\
\hline Plastic material reduction $(\mathrm{kg})$ & 250 & 400 \\
\hline Electric energy reduction $(\mathrm{kWh})$ & 1,110 & 2,910 \\
\hline Water consumption (liter) & 70 & 3,000 \\
\hline
\end{tabular}

The absolute quantities shown in Table 3 might be, at a first glance, considered small, but reductions in the consumption of material and energy brought significant advantages to the company. The consumption decrease was due to the implementation of some improvement opportunities presented in the technical guide [8]: efficient lighting, translucent tiles and lighting sensors, dispensers and automatic feeders, compressed air loss control, introduction of energy diagnosis, reuse of in-process material, waste recycling (outside process), etc.

External indicators (Material intensity evaluation and water footprint) - This method, developed at the Wuppertal Institute by Ritthoff et al [13], is a practical application of the material input per service concept (MIPS) to evaluate the environmental harm associated with the extraction or diversion of resources from their natural flows and cycles. Material intensity factors (g/unit) are multiplied by each saving (material or energy), respectively, accounting for the total amount of abiotic and biotic matter, water and air, that are no 
longer required in order to provide that material to the company. According to Hoekstra [14], water footprint is the total amount of freshwater used directly and indirectly by a person, business, institution or country to produce the goods and services. The interest in the water footprint increased with the recognition that human impacts on freshwater systems is linked to products consumption, and that issues like water shortages and pollution can be better understood and addressed by considering production and supply chains as a whole. The water footprint concept can be used to quantify and map the water use behind consumption and how it can guide reduction of water use to a sustainable level. Table 4 shows the values of material intensities and water footprint of the selected individual savings achieved by CP interventions.

Table 4 - Material intensity and water footprint

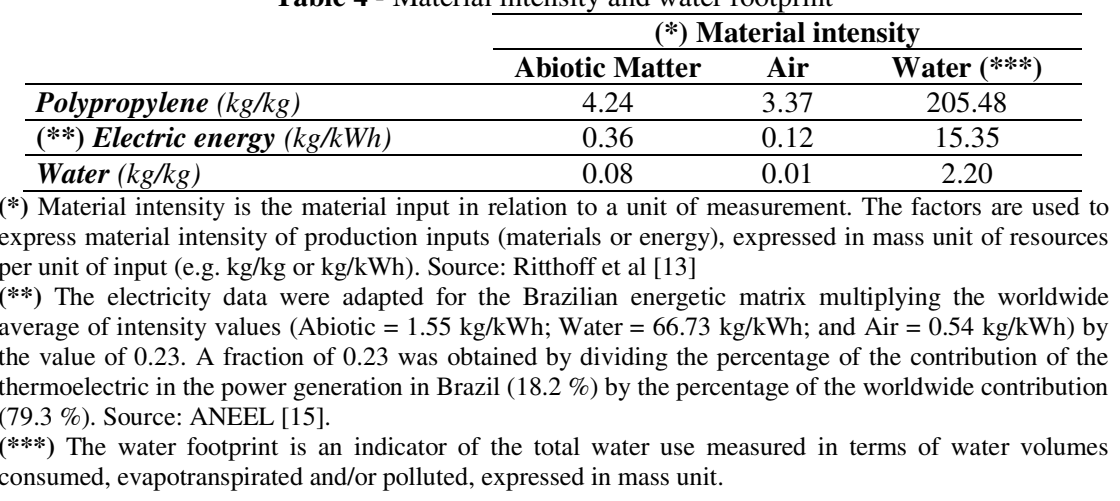

A considerable environmental benefit is related to the avoidance of environmental impact associated with the extraction or diversion of resources from their natural ecosystem pathways. The water footprint quantifies the water use behind consumption and how it can guide reduction of water use to a sustainable level. Table 5 summarizes the material savings in the three environmental compartments (abiotic matter, air and water) achieved by CP interventions. The water compartment corresponds to the reduction in the water footprint.

Table 5. Material and water savings due to $\mathrm{CP}$ interventions.

\begin{tabular}{cccc}
\cline { 2 - 4 } Company & \multicolumn{3}{c}{ Material savings $(\mathrm{kg})$} \\
\cline { 2 - 4 } & Abiotic matter & Air & Water $(*)$ \\
\hline $\boldsymbol{D}$ & 1,465 & 976 & $\mathbf{6 8 , 5 6 2}$ \\
\hline $\boldsymbol{G}$ & 2,983 & 1,757 & $\mathbf{1 3 3 , 4 6 0}$ \\
\hline (*) Total reduction in water footprint, showing the total water saved, expressed in mass unit (kg).
\end{tabular}

It can be observed that the relatively small quantities of materials saved within the companies led to huge external preservation of materials, in particular water.

External indicators (Carbon footprint) - The carbon footprint is a measure of the total amount of carbon dioxide $\left(\mathrm{CO}_{2}\right)$ emissions that is directly and indirectly caused by an activity, or is accumulated over the life stages of a product. This includes activities of individuals, populations, governments, companies, organizations, processes, industry sectors etc. Products include goods and services. According to Wiedmann and Minx [16], in any case, all direct (on-site, internal) and indirect (off-site, external, embodied, upstream, downstream) emissions need to be taken into account. Only $\mathrm{CO}_{2}$ is included in the analysis, being well aware that there are other substances with greenhouse warming potential. However, many of those are either not based on carbon or are more difficult to quantify because of data availability. Tables 6 and 7 show the values of carbon footprint intensities for plastic and electric energy. 
Table 6 - Carbon footprint intensity for plastic.

\begin{tabular}{lcccc}
\cline { 2 - 5 } & $\begin{array}{c}\text { (i) Intensity of energy } \\
\text { contained in the fuel used in } \\
\text { material transportation } \\
(\mathrm{MJ} / \mathrm{kg})\end{array}$ & $\begin{array}{c}\text { (ii) Intensity of } \\
\text { energy contained } \\
\text { in the raw material } \\
(\mathrm{MJ} / \mathrm{kg})\end{array}$ & $\begin{array}{c}\text { (i+ii) Total } \\
\text { intensity of } \\
\text { fossil energy } \\
(\mathrm{MJ} / \mathrm{kg})\end{array}$ & $\begin{array}{c}(*) \text { Intensity of } \\
\text { indirect } \mathrm{CO}_{2} \\
\text { emissions } \\
\left(\mathrm{kg} \mathrm{CO}_{2} / \mathrm{kg}\right)\end{array}$ \\
\hline $\begin{array}{l}\text { Plastic material } \\
\text { (from crude oil) }\end{array}$ & 39.70 & 51.20 & 90.90 & $\mathbf{6 . 9 9}$ \\
\hline
\end{tabular}

(*) Intensity of indirect $\mathrm{CO}_{2}$ emissions obtained by multiplying the total intensity of fossil energy by the value of $76.92 \times 10^{-3} \mathrm{kgCO}_{2} / \mathrm{MJoe}$ (oe = oil equivalent). Source: Brown and Ulgiati, 2002 [17].

Table 7 - Carbon footprint intensity for electric energy.

\begin{tabular}{cccc}
\hline $\begin{array}{c}\text { Electricity generated } \\
\text { in thermoelectric }\end{array}$ & $\begin{array}{c}(*) \text { Intensity of } \mathrm{CO}_{2} \\
\text { emissions } \\
(\mathrm{kg} \mathrm{CO} / \mathrm{kWh})\end{array}$ & $\begin{array}{c}(* *) \text { Contribution } \\
\text { according to the Brazilian } \\
\text { energy matrix }(\%)\end{array}$ & $\begin{array}{c}\text { Intensity of indirect } \\
\mathrm{CO}_{2} \text { emissions } \\
\left(\mathrm{kg} \mathrm{CO}_{2} / \mathrm{kWh}\right)\end{array}$ \\
\hline Gas & 0.60 & 10.3 & 0.062 \\
Oil & 0.97 & 5.6 & 0.054 \\
Coal & 1.08 & 2.3 & 0.025 \\
\hline \multicolumn{5}{c}{ Total } & & $\mathbf{0 . 1 4 1}$
\end{tabular}

(*) Source: Herendeen, 1998 [18].

(**) Source: ANEEL [15].

The companies D and $\mathrm{G}$ carbon footprints (expressed in mass unit $\mathrm{kg} \mathrm{CO}_{2}$ ), saved after $\mathrm{CP}$ interventions are shown in table 8 . It can be observed that the $\mathrm{CP}$ interventions on reduction of raw material accounts for practically $90 \%$ of $\mathrm{CO}_{2}$ emission reduction.

Table 8 - Carbon footprint intensity reduction due to $\mathrm{CP}$ interventions.

\begin{tabular}{|c|c|c|}
\hline $\begin{array}{c}\text { Comp } \\
\text { anies }\end{array}$ & CP Interventions & \begin{tabular}{|c|} 
Carbon \\
Footprints
\end{tabular} \\
\hline \multirow[b]{2}{*}{$D$} & $250 \mathrm{~kg}$ plastic reduction $/ \mathrm{t}_{f p} \times 6.99 \mathrm{~kg} \mathrm{CO} / \mathrm{kg}=1,747.5 \mathrm{~kg} \mathrm{CO}_{2}$ & $1,904 \mathrm{~kg}$ \\
\hline & $1,110 \mathrm{kWh}$ electric energy reduction $/ t_{f p} x 0.141 \mathrm{~kg} \mathrm{CO}_{2} / \mathrm{kWh}=156.5 \mathrm{~kg} \mathrm{CO}{ }_{2}$ & $\mathrm{CO}_{2}$ \\
\hline \multirow[b]{2}{*}{$\mathrm{G}$} & $400 \mathrm{~kg}$ plastic reduction $/ \mathrm{t}_{f p} x 6.99 \mathrm{~kg} \mathrm{CO} / \mathrm{kg}=2,796.0 \mathrm{~kg} \mathrm{CO}{ }_{2}$ & $3,206 \mathrm{~kg}$ \\
\hline & $2,910 \mathrm{kWh}$ electric energy reduction $/ t_{f p} x 0.141 \mathrm{~kg} \mathrm{CO} / \mathrm{kWh}=410.3 \mathrm{~kg} \mathrm{CO} 2$ & $\mathrm{CO}_{2}$ \\
\hline
\end{tabular}

\section{Conclusions}

The qualitative research has been performed in eight companies in the plastic manufacturing sector and, due to the results relevance, it can be inferred that the proposed evaluation model allows identifying organizations that are effectively managing their processes through cleaner production principles and therefore possess the necessary requirements to obtain favorable environmental results. The multiple case study helped to select two companies that handled more than $90 \%$ of the model requirements, compared with the percentage of compliance of 85,75 and $56 \%$ from the other companies. After being identified by the model as having structured and standardized management processes these companies ( $D$ and $G$ ) demonstrated the deployment of more than ten opportunities for cleaner production presented in the cleaner production technical guide [8] and showed a reduction in the consumption of water, electrical energy and raw material in the last three years.

The results of external performance indicators allowed to look at the consumption decreases from the perspective of nature and showed that even small internal changes to the company can bring big benefits to the environment and society that would not be perceived with restricted use of internal indicators. With these multiple case study findings it is expected that the leading companies in the sector include concepts of cleaner production into their management processes to assist them in developing improved operational processes and obtaining favorable and sustainable environmental results. This will cause 
the follower companies adopt similar strategies in their management systems, making the concepts of environmental management to solidify in the producing and recycling of plastic industry.

\section{Acknowledgements}

The authors thank SINDIPLAST for data and information supplied and PROSUP / CAPES for the financial support in the form of a PhD scholarship.

\section{References}

1. Stone, L.: When case studies are not enough: the influence of corporate culture and employee attitudes on the success of cleaner production initiatives. Journal of Cleaner Production, vol. 8, pp. 353-359 (2000)

2. Taylor, B.: Encouraging industry to assess and implement cleaner production measures. Journal of Cleaner Production, vol. 14, pp. 601-609 (2006)

3. Vendrametto, O.; Palmeri, N.; Oliveira Neto, G.C.; Perreti, O.D.: Cleaner production: A growing movement in brazilian companies. Produção Online, vol. 10, n. 1, pp. 4970 (2010)

4. Gonçalves, J.E.L.: As empresas são grandes coleções de processos (in Portuguese). Revista de Administração de Empresas, vol. 40, n.1, pp. 6-19 (2000)

5. AFNOR - Association Française de Normalisation - FD X 50-176, Management des processus. La Plaine St Denis Cedex, France (2005)

6. Rummler, G.A.; Brache, A.P.: Improving performance: how to manage the white space on the organizational chart. San Francisco: Jossey-Bass (1991)

7. Giannetti, B.F.; Almeida, C.M.V.B.: Industrial Ecology: concepts, tools and applications (in Portuguese). São Paulo: Edgard Blucher (2006)

8. CETESB - Companhia de Tecnologia de Saneamento Ambiental. Guia ambiental da indústria de transformação e reciclagem de materiais plásticos. Série $\mathrm{P}+\mathrm{L}$ (in Portuguese). São Paulo, Brasil (2011)

9. Buccelli, D.O.; Costa Neto, P.L.O.: Prêmio nacional da qualidade: Gestão da qualidade ou qualidade da gestão? In: XXXIII Encontro Nacional de Engenharia de Produção. Salvador: Abepro (2013)

10. Leonard-Barton, D.: A dual methodology for case studies: Synergistic use of a longitudinal single site with replicated multiple sites. Organization Science, vol. 1, Issue 3, pp. 248-266 (1990)

11. Yin, R.K.: Case Study Research: Design and Methods. Thousand Oaks: Sage Publications (1994)

12. Giannetti, B.F.; Bonilla, S.H.; Silva, I.R.; Almeida, C.M.V.B.: Cleaner production practices in a medium size gold-plated jewelry company in Brazil: when little changes make the difference. Journal of Cleaner Production, vol. 16, pp. 1106-1117 (2008)

13. Ritthoff, M.; Rohn, H.; Liedtke, C.; Merten, T.: Calculating MIPS: Resources productivity of products and services. Wuppertal Institute for Climate, Environment and Energy, North Rhine-Westphalia. Wuppertal Spezial 27e, (2002)

14. Hoekstra, A.Y.: The Water Footprint of Modern Consumer Society. London: Routledge (2013)

15. ANEEL - Agência Nacional de Energia Elétrica (accessed in 24/08/2013) http://www.aneel.gov.br/aplicacoes/capacidadebrasil/OperacaoCapacidadeBrasil.asp

16. Wiedmann, T.; Minx, J.: A Definition of 'Carbon Footprint'. In: Pertsova, Carolyn C., Ecological Economics Research Trends. Chapter 1, pp. 1-11, Hauppauge: Nova Science Publishers (2008)

17. Brown, M.T.; Ulgiati, S.: Emergy evaluations and environmental loading of electricity production systems. Journal of Cleaner Production, vol. 10, pp. 321-334 (2002)

18. Herendeen, R.A.: Ecological Numeracy: Quantitative Analysis of Environmental Issues. New York: John Wiley \& Sons Incorporated (1998) 